\title{
Népirtás-e az örmény népirtás a nemzetközi jog fényében?
}

Valójában senki nem vitatja, hogy az I. világháború idején, 1915-ben és az azt követő években az Oszmán Birodalom területén, mindenekelőtt az Anatóliában élő örmény lakosság nagyon súlyos atrocitások áldozata volt. 1915-ben a Talât pasa belügyminiszter kezdeményezésére elfogadott Tehcir-törvény a birodalom területén élő örmények kitelepítését írta elő. A háborús körülmények között a hivatalosan áttelepítésnek nevezett akció rendkívül brutális következményekkel járt, becslések szerint több mint 1,5 millió örmény, szír, görög és más keresztény csoporthoz tartozó ember pusztult el, korabeli beszámolók szerint nők ezrei vagy tízezrei lettek nemi erőszak áldozatai, több tízezer gyermeket szakítottak el eröszakkal szüleiktől, és adtak török családokhoz, helyeztek el török árvaházakban. ${ }^{1}$ Az áttelepítés és a hozzá kapcsolódó támadások, gyilkosságok nemcsak az örmény lakosság döntő részét tüntették el a mai Törökország területéröl, hanem az örmények magántulajdonának kisajátításával, kulturális, egyházi épületeik rombolásával is pótolhatatlan károkat okoztak. A nemzetközi közösség már az események idején is felháborodással értesült ezekröl a szörnyüségekről, több állam tiltakozott ellene, például az Egyesült Államok kormánya nevében Lansing külügyminiszter 1915 júliusában utasította az USA isztambuli nagykövetét, hogy tegyen meg mindent az örmények üldözésének megakadályozásáért. ${ }^{2}$ Söt, 1915. május 24-én Franciaország, Nagy-Britannia és Oroszország közös nyilatkozatban ítélte el az eseményeket, amelyeket az „emberiesség és civilizáció elleni büncselekményeknek" minösítettek. ${ }^{3}$ Ez a nemzetközi büntetőjog fejlődése szempontjából is fontos

* A szerző jogász, a TK Kisebbségkutató Intézetének kutatóprofesszora, az NKE docense. E-mail: vizi.balazs@tk.hu

1 Dadrian, Vakhan N.: The History of the Armenian Genocide: Ethnic Conflict from the Balkans to Anatolia to the Causasus. Providence RI: Berghahn Books, 1997; Botos Máté - Kovács Bálint (szerk.): Az emlékezet száz éve. Így látja az utókor az örmény népirtást. Budapest: L’Harmattan, 2019; Krajcsir Piroska: A XX. század első népirtása. Deliberationes, különkiadás 2015/2. 88-98.

2 Idézi az Egyesült Államok Képviselőházának 2019-es, az örmény népirtásról megemlékezö határozata. H. Res. 296. (29 October 2019) https:/www.congress.gov/116/bills/hres296/ BILLS-116hres296eh.pdf (letöltés ideje: 2021. január 23.)

3 Hoffmann Tamás: Az emberiesség elleni büncselekmények nemzetközi és magyar jogi szabályozása. Állam- és Jogtudomány, 2017/1. 34. 
nyilatkozat elöször vetette fel annak lehetőségét, hogy egy ország saját polgárai ellen elkövetett háborús büncselekményekért induljon büntetőjogi felelösségre vonás. Az örményekkel szemben elkövetett atrocitások miatt az antanthatalmak által a háború felelőseinek megállapítására létrehozott bizottság nemzetközi törvényszék felállítását is javasolta, amelynek célja az lett volna, hogy a humanitás jogának megsértése miatt indítandó büntetőeljárásokat lefolytassa. Az Egyesült Államok és Japán képviselőinek ellenállása miatt - akik úgy gondolták, egy ilyen utólagosan indított eljárásban sérülne a nullum crimen sine lege elve, hiszen az elkövetéskor ilyen büncselekmények nem voltak - ez a javaslat elbukott. ${ }^{4}$ A sèvres-i békeszerződésben még szerepelt egy kitétel, hogy ,a török kormány kötelezettséget vállal arra, hogy átadja a Szövetséges Hatalmaknak azokat a személyeket, akiket felelősnek tartanak a Török Birodalom területén elkövetett mészárlásokért az 1914. augusztus 1-től kezdődő háborúban". ${ }^{5}$ De a sèvres-i békeszerződés sosem lépett hatályba, és a helyébe lépő lausanne-i békeszerződés nem tartalmazott ilyen rendelkezést. Ennek ellenére török hadbíróságok elött 1919-1922 között több eljárás is indult az elkövetők megbüntetésére, igaz, ezek az eljárások csak részben zárultak eredményesen. ${ }^{6}$

A közbeszédben „örmény népirtásként” hivatkoznak rendszerint ezekre az eseményekre, a közelmúltban az Európa Tanács Parlamenti Közgyülése ${ }^{7}$ és az Európai Parlament ${ }^{8}$ külön határozatban ismerte el az örmény népirtást, ahogy ez a századik évforduló kapcsán több országban is megtörtént. ${ }^{9}$ A török kormány ugyanakkor következetesen és határozottan tiltakozik az ellen, hogy az örmény népcsoport által elszenvedett tragédiát népirtásnak nevezzék. ${ }^{10}$ Sőt, büntetőjogi eszközökkel is felléphet azok ellen, akik a nyilvánosság előtt népirtásnak nevezik az 1915-ös eseményeket. ${ }^{11}$

4 Uo.

5 Idézi, uo.

6 Dadrian, Vakhan N.: Genocide as a Dual Problem of National and International Law. University of St. Thomas Journal of Law and Public Policy, 2010 (4.) 60-82.

7 Council of Europe Parliamentary Assembly, Doc. 9056 2nd edition 14 May 2001 Recognition of the Armenian genocide Written Declaration No. 320.

8 Az Európai Parlament 2015. április 15-i állásfoglalása az örmény népirtás századik évfordulójáról (2015/2590(RSP))

9 Az Egyesült Államok Kongresszusán kívül mások mellett a cseh parlament 2017-ben, a francia szenátus 2016-ban, a német Bundestag 2016-ban; a teljes lista az örmény külügyminisztérium honlapján érhető el: https:/www.mfa.am/en/recognition/ (letöltés ideje: 2021. január 23.)

10 A török kormány álláspontját 1. http://www.mfa.gov.tr/the-armenian-allegation-of-genocide-the-issue-and-the-facts.en.mfa (letöltés ideje: 2021. január 23.)

11 2006-ban Altuğ Taner Akçam török történésszel szemben azért indult eljárás, mert egy örmény-török kétnyelvü lapban írt véleménycikket arról, hogy szerinte az 1948-as genocídium egyezmény értelmében az örmények elleni 1915-ös atrocitások kimerítik a népirtás fogalmát. Az ügy végül az Emberi Jogok Európai Bírósága elé került, amely 2011-ben kimondta, hogy Törökország megsértette az Emberi Jogok Európai Egyezményének 10. cikkét, így a panaszos 
Nem véletlen, hogy a „népirtás” fogalmának használata ennyire heves vitát vált ki, ugyanis a II. világháború vége, különösen az 1948-as, a népirtás tilalmáról szóló egyezmény ${ }^{12}$ (ún. genocídium egyezmény, a továbbiakban Egyezmény) elfogadása óta a fogalom használata nemcsak politikailag terhelt és rendkívül kényes, ${ }^{13}$ hanem a nemzetközi jog alapján is komoly következményekkel jár. ${ }^{14} \mathrm{Ez}$ a cikk röviden azt a kérdést járja körül, hogy van-e jelentősége ma annak, hogy minek nevezzük ezeket az eseményeket (népirtásnak vagy más büncselekményeknek), lehet-e ma relevanciája a nemzetközi jognak az örmény népirtás megítélésében, értelmezésében, elsősorban az Egyezmény rendelkezéseinek fényében.

\section{A népirtás fogalma a nemzetközi jogban}

Az emberiség történetében számos alkalommal történt meg, hogy egy nép leigázása annak megsemmisítésével is együtt járt. Ahogy Jean-Paul Sartre fogalmazott: „A genocídium egyidős az emberiséggel. Egyetlen társadalmat sem óvott meg eddig a struktúrája ennek a bünnek az elkövetésétől. Minden genocídium a történelem terméke, és magán viseli annak a társadalomnak a nyomát, amelyben elkövették." ${ }^{15}$ Bár maga a népirtás ősidők óta velünk élő jelenség, a genocídium fogalmát Raphael Lemkinhez kötjük, aki a görög ,genosz” (nép, nemzetség, nemzet) és a latin ,caedere” (gyilkolni) szavakból alkotta azt meg a homicídium (emberölés) vagy tyrannocídium (zsarnokgyilkosság) mintájára. ${ }^{16}$ Lemkin a II. világháború során a nácik által elkövetett rémtettek leírására használta ezt a fogalmat, amelyek célja egy nemzet, etnikai csoport módszeres felszámolása volt. A Nürnbergi Törvényszék előtt az Einsatzgruppe-ügyben ugyan a vád részéről már használták a ,genocídium" kifejezést, bár még nem abban az értelemben, hogy sui generis büncselekmény volna. ${ }^{17}$ De igen hamar, 1946-ban megjelent az ENSZ Közgyülésének

szólásszabadsághoz való jogát. Altuğ Taner Akçam v. Turkey, (Application no. 27520/07) 25 October 2011. (Köszönöm Hoffmann Tamásnak, hogy erre az ügyre és több más részletre is felhívta a figyelmem, amellyel teljesebb lett ez a tanulmány.)

12 A népirtás bűntettének megelőzése és megbüntetése tárgyában 1948. évi december 9. napján kelt nemzetközi egyezmény. Magyarországon kihirdette az 1955. évi 16. tvr. http://njt.hu/ cgi_bin/njt_doc.cgi?docid=366.614 (letöltés ideje: 2021 . január 23.)

13 L. Gulyás Éva: A genocídium fogalmának változásai. Gondolatok az 1948-as genocídium egyezmény 70. évfordulóján. Regio, 2018/3. 5-61.

14 Lamm Vanda: Genocídium - a nemzetközi jog és a büntetőjog határterülete. Állam- és Jogtudomány, 2011/4. 457-476.

15 Idézi Thornberry, Patrick: International Law and the Rights of Minorities. Oxford: Clarendon Press, 1991. 60.

16 Lemkin, Raphael: Axis Rule in Occupied Europe. Washington: Carnegie Endowment, 1944.

17 L. Earl, Hilary: Prosecuting genocide before the Genocide Convention: Raphael Lemkin and the Nuremberg Trials, 1945-1949. Journal of Genocide Research, vol. 15. (2013) 319. 
a népirtás bűncselekményéről szóló határozatában, ${ }^{18}$ és az 1948-ban elfogadott Egyezménnyel a nemzetközi jogi fogalomtár része lett. A népirtás tilalmának jelentősége megkérdőjelezhetetlen, azt a ius cogens részének tekinthetjük, ami nemcsak az Egyezményt ratifikáló 152 államot köti: már 1951-ben a Nemzetközi Bíróság az Egyezményhez füzött fenntartásokkal kapcsolatban kiadott tanácsadó véleményében úgy fogalmazott, hogy ,az Egyezmény olyan elvekre épül, amelyeket, minden szerződéses kötelezettség nélkül is, a civilizált nemzetek az államokra kötelezőnek ismernek el". ${ }^{19}$

Eredetileg Lemkin nemcsak egy népcsoport fizikai megsemmisítésére szükítette a genocídium fogalmát, hanem - a nácik gyakorlatából kiindulva - úgy gondolta, az különböző területeken valósulhat meg. Így munkájában megemlítette a „politikai genocídiumot”, ami egy nemzeti kormány teljes felszámolását és a náci igazgatás bevezetését jelentette. A „társadalmi genocídium”-on a nemzet szellemi erőinek, különösen értelmiségének felszámolását értette; míg „,kulturális genocídiumnak" nevezte a helyi nyelvek felszámolását, a náci ideológia kizárólagos szerepét az oktatásban és a kultúra szigorú irányítását, beleértve könyvtárak, kulturális emlékek megsemmisítését. Ugyanígy a „gazdasági genocídium” a nemzet gazdasági erőforrásainak felszámolását jelentette; a „biológiai genocídium” pedig a nem német népesség körében alkalmazott erőszakos születésszabályozási intézkedéseket, amelyekkel a nem német lakosság reprodukciós képességét csökkentették. Míg „fizikai genocídiumnak” az egyes csoportokkal szemben elkövetett legszörnyübb tömeggyilkosságokat nevezte. ${ }^{20}$

A népirtás tilalmáról szóló egyezmény előkészítése során felmerült, hogy a világháborús tapasztalatoknak megfelelően tágan értelmezzék a genocídium fogalmát, így az Egyezményt szövegező bizottságban olyan javaslat is felmerült, hogy „az Egyezmény értelmében a genocídium minden olyan szándékos cselekedet is, amelyet azzal a szándékkal követnek el, hogy egy nemzeti, faji vagy vallási csoport tagjainak nemzeti vagy faji származása vagy vallásos hite alapján nyelvét, kultúráját vagy vallását megsemmisítsék, 1 . a csoport nyelvének hétköznapi vagy iskolai használatának vagy a csoport nyelvén született kiadványok nyomtatásának, terjesztésének megtiltásával; 2. a csoport történelmi intézményei és tárgyai, iskolái, múzeumai, könyvtárai használatának tiltásával vagy megsemmisítésével". ${ }^{21}$ Az Egyezmény szövegezésekor vita volt arról is, hogy pontosan milyen csoportok szerepeljenek a felsorolásban, az államok képviselöi között volt olyan vélemény, amely a vallási csoportokat kihagyta volna, arra hivatkozva, hogy annak tagjai

18 UN General Assembly, The Crime of Genocide, 11 December 1946, A/RES/96, elérhető: https://www.refworld.org/docid/3b00f09753.html (letöltés ideje: 2021. január 24.)

19 Reservations to the Convention on Genocide, Advisory Opinion: I. C. J. Reports (1951), 23.

20 Lemkin, 1944. IX. fejezet.

21 UN Doc A/362, in GAOR, 2nd session 6th Committee, Summary Records, 16 September - 26 November 1947. 
bármikor kiléphetnek a vallási közösségböl, de végül ezt elvetették. Az első szövegtervezetben a nyelvi csoportok is szerepeltek, de a kormányok képviselői úgy vélték - amúgy vitatható módon -, hogy nem lehet a fajtól, nemzeti vagy vallási csoporttól teljesen független nyelvi csoportokról beszélni. A legfontosabb kérdésnek az látszott, hogy a meghatározott csoportok felsorolása kellően tág és a népirtást megvalósító cselekmények köre lehetőleg pontosan behatárolható legyen. ${ }^{22}$

Így született meg az egyezmény 2. cikke, amely így fogalmaz: „A jelen Egyezmény népirtás alatt a következő cselekmények bármelyikének, valamely nemzeti, népi, faji vagy vallási csoport mint olyan teljes vagy részleges megsemmisítésének szándékával való elkövetését érti:

a) a csoport tagjainak megölése;

b) a csoport tagjainak súlyos testi vagy lelki sérelem okozása;

c) olyan életfeltételek ráerőszakolása a csoportra, melyeknek célja a csoport teljes vagy részleges fizikai elpusztulásának előidézése;

d) olyan intézkedések tétele, amelyek célja a csoporton belül a születések meggátolása;

e) a csoport gyermekeinek más csoporthoz való erőszakos átvitele."

A Lemkin által használt kategóriák szerint tulajdonképpen ez a definíció a „fizikai genocídiumhoz" áll a legközelebb, így a népirtást az adott csoport fizikai-biológiai megsemmisítésének céljával lehet elkövetni, ahogy ezt a későbbi joggyakorlat is igazolta. ${ }^{23}$ Így például a kultúra, a nyelv megsemmisítése önmagában nem minősül annak. ${ }^{24}$ Ennek igazán azért van jelentősége, mert szűken behatárolja, egyáltalán mely cselekmények merítik ki a nemzetközi jog alapján a népirtás fogalmát. ${ }^{25}$

A bírói gyakorlat azonban árnyalja ezt a megszorító értelmezést. A volt Jugoszlávia területén elkövetett büntetteket vizsgáló Nemzetközi Törvényszék (ICTY) a Krstić-ügyben eljáró tanácsa kimondta, hogy egy csoport fizikai, biológiai megsemmisítésére irányuló cselekmények gyakran magukkal vonják a kulturális vagy

22 Thornberry, 1991. 67-71.

23 Ezt a meghatározást vette át szó szerint a Ruandai Nemzetközi Törvényszék (ICTR), a volt Jugoszlávia Nemzetközi Törvényszék (ICTY) és Nemzetközi Büntetőbíróság statútuma is. Statute of the International Criminal Tribunal for the Prosecution of Persons Responsiblefor Genocide and Other Serious Violations of International Humanitarian Law Committed inthe Territory of Rwanda and Rwandan Citizens Responsible for Genocide and Other Such Violations Committed in the Territory of Neighboring States, S.C. Res. 955, U.N. SCOR, 3453d Mtg. at 3., U.N. Doc. S/RES/955, Annex (1994); Statute of the International Criminal Tribunal for the Prosecution of Persons Responsible for Serious Violations of International Humanitarian Law Committed in the Territory of the Former Yugoslavia Since 1991, U.N. Doc. S/25704, Annex; Rome Statute of the International Criminal Court, United Nations, Treaty Series, vol. 2187, No. 38544.

24 Cassese, Antonio et al.: Cassese's International Criminal Law. Oxford: OUP, 2013. 3rd ed. 443.

25 Vö.: Kardos Gábor: A népirtás és a nemzetközi jog fejlődése. Deliberationes, különkiadás $2015 / 2$. 
a vallási tulajdon megsemmisítését, ami - egyéb bizonyítékok mellett - arra is utalhat, hogy az elkövetők szándéka a csoport fizikai megsemmisítése volt. ${ }^{26}$

Az örményeket ért atrocitások között kiemelt szerepe van az örmény kulturális és épített örökség megsemmisítésének, az örmény magántulajdon kisajátításának, amelyet egyes szerzők népirtó vagyonelkobzásnak neveznek. ${ }^{27} \mathrm{~A}$ fentiek alapján ugyan a tulajdont vagy a kulturális javakat megsemmisítő cselekmények a nemzetközi jog szerint nem merítik ki önmagukban a népirtás büncselekményét, de igazolhatják a népirtó szándékot.

\section{A népirtás tilalmáról szóló egyezmény alkalmazhatóságának kérdése}

A nemzetközi büncselekmények, mint a népirtás üldözése nemcsak az egyes államok, de a nemzetközi közösség feladata is. A nemzetközi büntetőjog célja az elkövetök felelősségre vonása, ami a népirtás esetén is elsősorban az egyéneket érinti, de akár egy állam felelőssége is megállapítható (Egyezmény 9. cikk), bár erre eddig egyszer sem került sor. ${ }^{28} \mathrm{Az}$ örmény népirtás esetében az egyéni felelősségre vonás ma már értelmezhetetlen, mivel az elkövetők nincsenek életben. Törökország állami felelőssége szintén kérdéses, de még ha ezt kétséget kizáróan bizonyítani is lehetne, az Egyezmény alapján a visszaható hatály tilalma miatt felelősségre vonás nem indulhat el.

A nemzetközi jog általában tiltja a szerződések visszamenőleges hatályú alkalmazását: a szerződések jogáról szóló 1969-es bécsi egyezmény 28. cikke tulajdonképpen egy régóta fennálló szokásjogi normát erősít meg, ${ }^{29}$ amikor kimondja: „amennyiben a szerződésből eltérő szándék nem tünik ki, és ilyen szándék más módon sem állapítható meg, a részes felet nem kötik a szerződés rendelkezései olyan cselekmények és olyan tények vagy helyzetek tekintetében, amelyek akkor mentek végbe, illetve akkor szüntek meg, mielőtt a szerződés erre a félre nézve

26 Prosecutor v. Krstić (Case No. IT-98-33-A), para. 580.

27 Dickran Kouymjian: Az örmény tulajdon népirtó elkobzása és megsemmisítése. In: Botos Máté - Kovács Bálint (szerk.): Az emlékezet száz éve. Így látja az utókor az örmény népirtást. Budapest: L'Harmattan, 2019. 217-241.; Theriault, Henry C.: Legal Avenues for Armenian Genocide Reparations. International Criminal Law Review, 2014 (14.) 220-221.

28 2007-ben a Nemzetközi Bíróság bár nem állapította meg Szerbia felelősségét a srebrenicai népirtás elkövetésében, de kimondta, hogy Szerbia nem akadályozta azt meg. Application of the Convention on the Prevention and Punishment of the Crime of Genocide (Bosnia and Herzegovina v. Serbia and Montenegro), Judgment, I.C.J. Reports 2007, 43.

29 Vö.: A Nemzetközi Bíróság már 1952-ben, az Ambatielos-ügyben erre a következtetésre jutott, Greece v. U.K., Preliminary Objections, 1952 I.C.J. 27, 40 (July 1); International Law Commission, Reports of the Commission to the General Assembly, [1966] 2 Y.B. Int'1 L. Comm'n 169, 177, UN Doc. A/CN.4/SER.A/1966/Add.1. 
hatályba lépett volna". ${ }^{30}$ Az Egyezmény nem nyit utat arra, hogy rendelkezéseit visszaható hatállyal, a szerződés hatályba lépését megelőző időszakban elkövetett cselekményekre alkalmazzák. A genocídium egyezményböl ilyen szándékot nem lehet kiolvasni, és a travaux préparatoires sem utal arra, hogy az Egyezményt visszamenőleg is alkalmazni kívánták volna. Az Egyezmény egyértelműen jelen és jövő időben szól arról, hogy milyen cselekmények megbüntetését vállalják az államok, és a szövegezésben részt vevő delegáltak megszólalásaiból is az derül ki, hogy egy új büncselekmény kodifikációjáról és jövőbeni megelőzéséről, megbüntetéséről szóltak a tárgyalások. ${ }^{31}$

Így egyértelmủen állítható, hogy az 1910-es évek második felében a török állam területén elkövetett cselekmények miatt az Egyezményre hivatkozva egyetlen magánszemély vagy állam sem léphet fel jogi, pénzügyi vagy területi igénnyel. Ez azonban nem lehet akadálya annak, hogy magát a „népirtás” fogalmát ne használják olyan eseményekre, amelyek az Egyezmény hatályba lépését megelözően történtek, hiszen amint az az Egyezmény szövegezésének körülményeiből, a travaux préparatoires alapján is világos, maga a népirtás olyan történelmi tényeken alapul, amelyek korábbi időszakokban is megtörténtek. Ebből a szempontból az lehet releváns, hogy vajon a hivatkozott események megfelelnek-e a népirtás fogalmi követelményeinek. Az Egyezménynek abban lehet jelentősége, hogy vajon a népirtás fogalmát lehet-e alkalmazni az 1915-1916-os eseményekre.

\section{Népirtás vagy emberiesség elleni büncselekmények?}

Az Egyezmény 3-4. cikke nevesíti, hogy „a) népirtás; b) népirtás elkövetésére irányuló szövetkezés; c) közvetlen és nyilvános felbujtás népirtás elkövetésére; d) népirtás elkövetésének kísérlete; e) népirtásban való bünrészesség" cselekményeinek „,bármelyikét elkövető személyek büntetés alá esnek, függetlenül attól, hogy államvezetők, hivatalos vagy magánszemélyek”. Az Egyezmény értelmében a részes államok vállalják, hogy a népirtás megelőzése és megbüntetése érdekében szükséges nemzeti jogszabályokat fogadnak el (5-7. cikk), valamint a részes államok bármelyike az ENSZ szerveihez fordulhat, hogy azok „olyan rendszabályokat foganatosítsanak, amelyek véleményük szerint alkalmasak a népirtás vagy a III. cikkben felsorolt egyéb cselekmények bármelyikének megelőzésére

30 A szerződések jogáról szóló, Bécsben az 1969. évi május hó 23. napján kelt szerződés, Magyarországon kihirdette az 1987. évi 12. tvr.

31 Ezt részletesebben is elemzi az International Center for Transitional Justice 2002-es jelentése: The Applicability of the UN Convention on the Prevention and Punishment of the Crime of Genocide to Events which Occurred During the Early Twentieth Century, elérhetö: https:// www.ictj.org/publication/applicability-un-convention-prevention-and-punishment-crime-genocide-events-which (letöltés ideje: 2021. január 27.) 
és megszüntetésére" (8. cikk). A népirtás elkövetésének azonban lényegi feltétele, hogy ,valamely nemzeti, népi, faji vagy vallási csoport mint olyan teljes vagy részleges megsemmisítésének szándékával" kövessék el azt. Az ICTY egy másik jugoszláviai, a Jelisić-ügyben világosan kimondta, hogy mind a mentális elem (a védett csoportok teljes vagy részleges kiirtására irányuló szándék), mind a materiális elem (az Egyezmény 2. cikkének a), b), c), d), e) pontjában felsorolt cselekmények valamelyike) szükséges ahhoz, hogy egy büntettet népirtásnak lehessen nevezni. ${ }^{32}$

Az 1915-ös és az azt követő évek eseményei a korabeli beszámolók, visszaemlékezések, török bírósági eljárások adatai alapján ${ }^{33}$ a népirtás fogalmi feltételei közül legalább háromnak megfelelnek: a) embereket öltek meg, akik b) egy nemzeti, etnikai vagy vallási csoporthoz tartoztak, és c) ezeket a cselekményeket mások hasonló, a csoport ellen irányuló cselekedeteinek kontextusában lehetett értelmezni. Figyelmet érdemel, hogy az örmény gyerekek török árvaházakba kényszerítése vagy az ,áttelepítésben” érintett örmények erőltetett menetelésre kényszerítése (olyan körülmények között, amelyek egyértelmüen pusztulásukhoz vezettek) szintén kimerítik a népirtó cselekmények fogalmát. ${ }^{34}$ Azonban nemcsak az elkövetett cselekmények fontosak ebből a szempontból, hanem az elkövetői szándék is. Az Egyezmény 2. cikke a nevesített csoportok ,teljes vagy részleges megsemmisítésének szándékával való elkövetést" említi, ami azt jelenti, hogy a bünös tudat (mens rea) itt a kifejezett, különös szándékot (dolus specialis) jelöli, amellyel az elkövető egy csoport megsemmisítését kívánja, arra törekszik. Az eshetőleges szándék ebben az esetben nem elegendő, és a bizonyítási teher igen nagy a népirtó szándék igazolásán. ${ }^{35}$ Ugyanakkor a nemzetközi jogászok között ma is vita van afelöl, hogy vajon a különös szándék az egyedi népirtási cselekményben is tetten érhetö-e, vagy ehhez mindenképp olyan kontextus kell, amely másokkal együttmüködésben, mások hasonló, az érintett csoport megsemmisítését célzó cselekményeivel együtt teszi csak értelmezhetővé az egyedi szándékot. A kérdés valójában az, hogy egy átfogó terv részeként kell-e végrehajtani a cselekményt ahhoz, hogy azt népirtásnak minősíthessük. ${ }^{36} \mathrm{~A}$ szándékosságot az Egyezmény egyes részes államai is máshogy értelmezik, több állam is „előre kitervelt terv”, „,egyeztetett terv”

32 Jelisić (IT-95-10), és Biedermann Zsuzsanna: A genocídium fogalmának értelmezése. Jogelméleti Szemle, 2011/4. http://jesz.ajk.elte.hu/biedermann48.html (letöltés ideje: 2021. január 30.)

33 L. pl. Dadrian, Vakhan N.: Genocide as a Problem of National and International Law: The World War I Armenian Case and its Contemporary Legal Ramifications. Yale Journal of International Law, vol. 14. 1989. 291-315. és Dadrian, 2010.

34 Uo.

35 Application of the Convention on the Prevention and Punishment of the Crime of Genocide (Bosnia and Herzegovina v. Serbia and Montenegro), Judgement, I.C.J. Reports 2007, p. 43. para. 187.

36 Uo. para. 373. 
meglétét tekinti feltételnek, így például a török büntető törvénykönyv szerint népirtást csak terv alapján lehet elkövetni. ${ }^{37}$

Az igazi kérdés, hogy vajon az elkövetők szándéka kiterjedt-e arra, hogy az Oszmán Birodalom területén élő örményeket teljesen vagy részben megsemmisítsék, és milyen szerepe volt ebben az oszmán hatóságoknak. Dadrian még a világháborús években az elkövetőkkel szemben eljáró török katonai bíróságok eljárásainak perirataiból arra következtet, hogy 1918-1919-ben a korabeli török hatóságok is feltárták és elismerték az örmény népirtás körülményeit. Nemcsak a tömeggyilkosságokat, de azt is, hogy ezek vezető oszmán tisztviselők részvételével és irányításával történtek. Szerinte ez annak ellenére is kimondható, hogy a kemalista hatalomátvételt követően ezek az eljárások félbeszakadtak, és több, már meghozott ítéletet is semmissé nyilvánítottak. ${ }^{38}$ Ezzel szemben a török kormány következetesen azt képviseli, hogy nem lehet egyértelmüen bebizonyítani, hogy a korabeli oszmán tisztviselők valóban az örmények megsemmisítésének szándékával jártak volna el. A vitathatatlanul jelentős emberveszteség a hivatalos török álláspont szerint a háborús körülmények, egyéni túlkapások, az örményeket ért banditatámadások számlájára írható. ${ }^{39}$

Az 1948-as Egyezmény és a nyomában kialakult joggyakorlat az elkövető szándékát a népirtás büncselekményének lényegi feltételeként tekinti. Ezért ma már szinte lehetetlennek tủnik annak kiderítése, hogy a több mint száz évvel ezelőtti események résztvevőinek, a korabeli oszmán hivatalnokoknak mi volt az igazi szándéka: politikai fenyegetésnek tartották az örményeket, és ezért döntöttek az áttelepítésük mellett, vagy meg akarták valójában semmisíteni az örmény népet. Az ismert tények alapján annyit minden bizonnyal állíthatunk, hogy mai nemzetközi büntetőjogi fogalmaink szerint az örmények az Oszmán Birodalomban emberiesség elleni büncselekmények áldozatai lettek. ${ }^{40}$ Ezt támasztja alá az is, hogy már közvetlenül az események után több oszmán tisztviselö, maga a szultán és a nagyvezír is az emberiesség elleni büncselekménynek nevezte az eseményeket. ${ }^{41}$

Mindemellett a komoly tévedés veszélye nélkül feltételezhetjük, hogy az elkövetők között voltak olyanok, akár hivatalnokok is, akik azzal a céllal követték el ezeket a bűncselekményeket, hogy az anatóliai örményeket részben vagy egészben megsemmisítsék, így meglehetett bennük a különös népirtási szándék. Ezzel a megalapozott

37 Hoffmann, Tamás: The Crime of Genocide in Its (Nearly) Infinite Domestic Variety. In: Odello, Marco - Lubinski, Piotr (eds.): The Concept of Genocide in International Criminal Law. London: Routledge, 2020. 67-97.

38 Uo.

$39 \mathrm{http} / /$ www.mfa.gov.tr/controversy-between-turkey-and-armenia-about-the-events-of-1915. en.mfa (letöltés ideje: 2021. január 30.)

40 Vö.: Jacobs, Dov: Jumping Hurdles Backwards: The Armenian Genocide and the International Criminal Court, International Criminal Law Review, 2014. (14.) 274-290.

41 Dadrian, 2010. 
feltételezéssel pedig az 1948-as Egyezmény meghatározása alapján is igazolható, hogy történészek, jogászok vagy bárki népirtásnak nevezze mindazon eseményeket, amelyeknek az 1910-es évek második felében az örmények áldozatul estek az Oszmán Birodalom területén. ${ }^{42}$ Akkor is, ha ez a minősítés ma már, a visszaható hatály tilalma miatt, az Egyezmény alapján közvetlen jogi következményekkel nem járhat.

\section{A török állam felelőssége}

Bár az egyéni büntetőjogi felelősség megállapítása ma már lehetetlen, elméletben a török állam felelősségét is fel lehet vetni. Az államutódlásban konszenzus van, a mai Török Köztársaság az Oszmán Birodalom jogutódja ${ }^{43}$ természetesen az igazi kérdés az, az oszmán állam támogatta-e, megtervezte-e, és tisztviselőin keresztül aktívan részt vett-e az örmények ellen elkövetett nemzetközi büncselekményekben? Dadrian hosszan érvel amellett, a korabeli oszmán állam képviselőinek megszólalásait idézve, hogy bár mindent megtettek annak érdekében, hogy titokban tartsák, de tetten érhető, hogy az örmény népirtást az oszmán kormányzati hatalom központjában tervezték meg, szervezték és irányították. Igazolásként Talât pasát idézi, aki az örmények áttelepítéséről szóló döntés előtt a kormányülésen azt hangsúlyozta az örményekre utalva, hogy ,ezt a kellemetlen zavart alapvetően meg kell oldani és meg kell szüntetni" ${ }^{44}$ A török kormány hivatalos álláspontja évtizedek óta következetes abban, hogy nemcsak a népirtás fogalmának használatát tagadja, hanem azt is, hogy az örmények ellen tervezett, kormányzati irányítással végrehajtott üldözés indult volna el 1915-1916-ban. A századik évforduló közeledtével Recep Tayyip Erdoğan, akkor még miniszterelnökként, 2014-ben üzenetben fordult az örményekhez, amelyben kifejtette, hogy ,,az I. világháború incidensei közös fájdalmunk. [...] olyan események is történtek az I. világháború alatt, amelyeknek embertelen következményei voltak - mint az áttelepítés -, de ez sem kellene, hogy megakadályozza, hogy a török és az örmény nép együttérző és emberi kapcsolatokat ápoljon. [...] Azonban az elfogadhatatlan, hogy 1915-ös eseményeket Törökországgal szembeni ellenségeskedésre és politikai konfliktusok keltésére használják fel. ${ }^{.45}$ A török kormány hivatalos álláspontja szerint az I.. világháború idején az

42 The Applicability of the UN Convention on the Prevention and Punishment of the Crime of Genocide to Events which Occurred During the Early Twentieth Century. International Centre for Transitional Justice, 2002. elérhető: https://www.ictj.org/publication/applicability-un-convention-prevention-and-punishment-crime-genocide-events-which (letöltés ideje: 2021. január 27.)

43 Dadrian, 2010. 75.

44 Dadrian, 2010. 80.

45 The unofficial translation of the message of H.E. President Recep Tayyip Erdoğan, the then Prime Minister of the Republic of Turkey, on the events of 1915 (23 April 2014), elérhetö: http://www.mfa.gov.tr/turkish-prime-minister-mr_-recep-tayyip-erdo $\% \mathrm{C} 4 \% 9 \mathrm{Fan}$-published-a-message-on-the-events-of-1915_-23-april-2014.en.mfa (letöltés ideje: 2021. január 30.) 
Oszmán Birodalom területén is számtalan jogsértés történt, de ez nemcsak az örményeket, hanem minden más népcsoport tagjait érintette valamilyen formában, és ezek olyan zürzavaros időkben történtek, ahol a kormányzati felelősség felvetése értelmetlen. ${ }^{46}$

Az emberéletekben mérhető károkért, akár népirtásként, akár emberiesség elleni büncselekmények sorozataként tekintünk az 1915-1916-os eseményekre, a török állam jóvátételi felelőssége akkor lenne felvethető, ha egyetértés volna abban, hogy ezeket a cselekményeket az oszmán birodalmi kormány szervezte meg és hajtotta végre. Ahogy a holokauszt áldozatainak kárpótlását a Német Szövetségi Köztársaság kormánya magára vállalta, úgy egy ilyen - ma már értelemszerủen csak az áldozatok leszármazottait érintő - kárpótlási igény teljesítése döntően azon múlik, hogy azt a török kormány elismerje. ${ }^{47}$ Természetesen ebben az esetben, több mint egy évszázaddal az események után a leszármazottak azonosítása is komoly nehézségekbe ütközhet, de már több számítás is készült arról, hogy hány tíz- vagy százmilliárd dollár összegủ jóvátétel volna indokolt. ${ }^{48}$ Valószínütlennek látszik, hogy a török kormány jóvátételi felelősséget vállaljon az áldozatokért.

De ez nem lehet akadálya az anyagiakban, ingatlanokban esett károk, az ellenszolgáltatás nélkül elkobzott vagyon miatti kárpótlás felvetésének. ${ }^{49}$ Függetlenül az állami felelősség elismerésének ügyétől, az örmények elüzése után az örmények tulajdonát képező ingatlanok kártalanítás nélküli kisajátítása már akkor jogszerütlen lehetett. A magántulajdon kisajátításáért járó kártalanítás a 19. század óta minden jogrendben megjelent, egyedül a kommunista országok gyakorlata jelentett ez alól kivételt, amelyek ideológiai okokból tagadták ezt. A tulajdon védelmét azonban az államok tudják biztosítani, és ez csak annyiban nemzetközi jogi kérdés, hogy a II. világháború után a nemzetközi emberi jogi dokumentumok a tulajdonhoz való jogot is elismerik. Az Emberi Jogok Egyetemes Nyilatkozata (1948) 17. cikkében ezt így fogalmazza meg: „1. Minden személynek, mind egyénileg, mind másokkal együttesen joga van a tulajdonhoz. 2. Senkit sem lehet tulajdonától önkényesen megfosztani.” Az Emberi Jogok Európai Egyezményének első kiegészítő jegyzőkönyve 1. cikke pedig kimondja:

„Minden természetes vagy jogi személynek joga van javai tiszteletben tartásához. Senkit sem lehet tulajdonától megfosztani, kivéve, ha ez közérdekből és a törvényben meghatározott feltételek, valamint a nemzetközi jog általános elvei szerint történik.

\footnotetext{
46 http://www.mfa.gov.tr/controversy-between-turkey-and-armenia-about-the-events-of-1915. en.mfa (letöltés ideje: 2021. január 30.)

47 Vö.: Marboe, Irgmard: Compensation and Damages in International Law and their Relevance for the Valuation of Expropriated Armenian Property. International Criminal Law Review, 2014. (14.) 407-426.

48 Kouymjian, 2019. 224.

49 Uo.
} 
Az előző bekezdésben foglaltak nem korlátozzák az államok jogát olyan törvények alkalmazásában, melyeket szükségesnek ítélnek ahhoz, hogy a javaknak a köz érdekében történő használatát szabályozhassák, illetőleg az adók, más közterhek vagy bírságok megfizetését biztosítsák." ${ }^{50}$ Törökország 1954-ben ratifikálta az Emberi Jogok Európai Egyezményét, de az időbeliség, a visszaható hatály tilalma itt is érvényes, ezért az Emberi Jogok Európai Bírósága eddig egyetlen esetben sem tartotta befogadhatónak az örmény népirtáshoz kapcsolódó panaszokat. ${ }^{51}$ Abban az esetben, ha be lehetne bizonyítani, hogy egy jogtalan kisajátításra nem az 1910-es években került sor, hanem később, 1954 után - például azért, mert a török állam addig mondjuk csak vagyonkezelésében tartotta az ingatlant -, megfontolható lehet az Emberi Jogok Európai Egyezményének tulajdonjogot védő normáira hivatkozni.

Az állam nemzetközi jogi felelössége azonban az emberi jogok körén kívül nem igazán vethető fel saját állampolgáraival szemben. Természetesen vannak módszerek annak megállapítására, hogy általában a nemzetközi jogi felelösség körébe eső jogsértő cselekményekért milyen kártérítés, jóvátétel vagy elégtételadás lenne megfelelö, ahogy az is többféle módon számszerüsíthető, hogy ennyi idő elteltével a jogtalanul elkobzott vagy megsemmisített vagyon kárpótlási értéke mennyi lehetne, azonban ebben az esetben nehezen bizonyítható, hogy valóban nemzetközi jogsértés történt. ${ }^{52}$

Anélkül, hogy a török állam belső jogában vagy egy - például Örményországgal kötendő - nemzetközi szerződésben a felelősségét elvállalná, legfeljebb egy-egy egyéni kártérítési igénynek lehet sikere az EJEB előtt, amennyiben az igényre alapot adó jogsértés nem az Emberi Jogok Európai Egyezményének hatálybalépése elött történt, és másban is megfelel a strasbourgi bíróság előtti eljárás követelményeinek.

\section{Záró gondolatok}

Az, hogy a nemzetközi jog alapján az örmények nem kaphattak elégtételt az őket ért súlyos sérelmekért, nem jelenti azt, hogy hiábavaló volna az örmények évszázados küzdelme azért, hogy az elszenvedett sérelmeket népirtásnak ismerjék el: ezt

50 Magyarországon kihirdette az 1993. évi XXXI. tv.

51 Marboe, 2014. Legutóbb 2015-ben I. Aram kilikiai katholikosz fordult a strasbourgi bírósághoz a Sis/Kozan-i katholikoszátustól elvett ingatlanok visszaszolgáltatása ügyében, miután a török bíróságok elutasították kérelmét. Az Emberi Jogok Európai Bírósága befogadhatatlannak minősítette I. Aram beadványát, kivételesen arra hivatkozva, hogy a panaszos nem merítette ki Törökországban a jogorvoslati lehetőségeket. https://asbarez.com/168067/european-court-finds-catholicosates-suit-inadmissible-and-could-not-be-appealed/ (letöltés ideje: 2021. január 30.)

52 Marboe, 2014. 418-423. 
több állam és nemzetközi szervezet is megtette. ${ }^{53}$ Bár a modern nemzetközi büntetőjog és az emberi jogok nemzetközi védelmének a II. világháború után kialakult rezsimje korlátot állít az államok elé, hogy mit tehetnek meg saját állampolgáraikkal, ez az örményeket ért tragédia idején nem így volt. A jogi-anyagi jóvátétel így vitathatatlanul azon múlik elsősorban, hogy a török kormány hajlandó-e az állam felelősségét elismerni, és amennyiben ez esetleg a népirtásra is kiterjedne, az nagyon súlyos politikai és anyagi következményekkel is járhatna Törökország számára. Az elmúlt évszázadban kiderült, hogy az állami felelösség elismerésében a nemzetközi nyomás nem vezetett sikerre. Sajnos, Ottlik egyik hősét, Medve Gábort parafrazeálva: nem mindig lehet az igazság nehézágyúit bevonszolni olyan törékeny szerkezetekbe, amilyenek a nemzetközi viszonyok.

\section{FELHASZNÁLT IRODALOM}

Biedermann Zsuzsanna: A genocídium fogalmának értelmezése. Jogelméleti Szemle, 2011/4. http://jesz.ajk.elte.hu/biedermann48.html

Botos Máté - Kovács Bálint (szerk.): Az emlékezet száz éve. Így látja az utókor az örmény népirtást. Budapest: L'Harmattan, 2019.

Cassese, Antonio et al.: Cassese's International Criminal Law. Oxford: OUP, 2013. 3rd ed. 443.

Dadrian, Vakhan N.: Genocide as a Dual Problem of National and International Law. University of St. Thomas Journal of Law and Public Policy, 2010 (4). 60-82.

Dadrian, Vakhan N.: Genocide as a Problem of National and International Law: The World War I Armenian Case and its Contemporary Legal Ramifications. Yale Journal of International Law, vol. 14. 1989. 291-315.

Dadrian, Vakhan N.: The History of the Armenian Genocide: Ethnic Conflict from the Balkans to Anatolia to the Causasus. Providence RI: Berghahn Books, 1997.

Earl, Hilary: Prosecuting genocide before the Genocide Convention: Raphael Lemkin and the Nuremberg Trials, 1945-1949. Journal of Genocide Research, vol. 15. (2013.) 319.

Gulyás Éva: A genocídium fogalmának változásai. Gondolatok az 1948-as genocídium egyezmény 70. évfordulóján. Regio, 2018/3. 5-61.

Hoffmann Tamás: Az emberiesség elleni büncselekmények nemzetközi és magyar jogi szabályozása. Állam- és Jogtudomány, 2017/1. 34.

Hoffmann, Tamás: The Crime of Genocide in Its (Nearly) Infinite Domestic Variety. In: Odello, Marco - Lubinski, Piotr (eds.): The Concept of Genocide in International Criminal Law. London: Routledge, 2020. 67-97.

53 Legutóbb Joe Biden, az Egyesült Államok elnöke is népirtásnak nevezte az eseményeket. https:/www.whitehouse.gov/briefing-room/statements-releases/2021/04/24/statementby-president-joe-biden-on-armenian-remembrance-day/ (letöltés: 2021 május 2.) 
Jacobs, Dov: Jumping Hurdles Backwards: The Armenian Genocide and the International Criminal Court, International Criminal Law Review, 2014. (14.) 274-290.

Kardos Gábor: A népirtás és a nemzetközi jog fejlődése. Deliberationes, különkiadás 2015/2.

Kouymjian, Dickran: Az örmény tulajdon népirtó elkobzása és megsemmisítése. In: Botos Máté - Kovács Bálint (szerk.): Az emlékezet száz éve. Így látja az utókor az örmény népirtást. Budapest: L'Harmattan, 2019. 217-241.

Krajcsir Piroska: A XX. század első népirtása. Deliberationes, különkiadás 2015/2. 88-98.

Lamm Vanda: Genocídium - a nemzetközi jog és a büntetőjog határterülete. Államés Jogtudomány, 2011/4. 457-476.

Lemkin, Raphael: Axis Rule in Occupied Europe. Washington: Carnegie Endowment, 1944.

Marboe, Irgmard: Compensation and Damages in International Law and their Relevance for the Valuation of Expropriated Armenian Property. International Criminal Law Review, 2014. (14.) 407-426.

Theriault, Henry C.: Legal Avenues for Armenian Genocide Reparations. International Criminal Law Review, 2014 (14.) 220-221.

Thornberry, Patrick: International Law and the Rights of Minorities. Oxford: Clarendon Press, 1991. 60.

\section{DOKUMENTUMOK}

Altuğ Taner Akçam v. Turkey, Application no. 27520/07, European Court of Human Rights, 25 October 2011.

Application of the Convention on the Prevention and Punishment of the Crime of Genocide (Bosnia and Herzegovina v. Serbia and Montenegro), Judgement, I.C.J. Reports 2007, p. 43.

Az Európai Parlament 2015. április 15-i állásfoglalása az örmény népirtás századik évfordulójáról (2015/2590(RSP)). Az Európai Unió Hivatalos Lapja, 2016-C-328/2

Council of Europe Parliamentary Assembly, Doc. 9056 2nd edition 14 May 2001 Recognition of the Armenian genocide Written Declaration No. 320.

Greece v. U.K., Preliminary Objections, 1952 I.C.J. 27, 40 (July 1); International Law Commission, Reports of the Commission to the General Assembly, [1966]2 Y.B. Int'1 L. Comm'n 169, 177, UN Doc. A/CN.4/SER.A/1966/Add.1.

International Center for Transitional Justice: The Applicability of the UN Convention on the Prevention and Punishment of the Crime of Genocide to Events which Occurred During the Early Twentieth Century https://www.ictj.org/publication/applicability-un-convention-prevention-and-punishment-crime-genocide-events-which 
Prosecutor $v$. Krstić - Case No. IT-98-33-A, ICTY

Reservations to the Convention on Genocide, Advisory Opinion: I.C.J. Reports (1951), 23.

Statute of the International Criminal Tribunal for the Prosecution of Persons Responsible for Genocide and Other Serious Violations of International Humanitarian Law Committed inthe Territory of Rwanda and Rwandan Citizens Responsible for Genocide and Other Such Violations Committed in the Territory of Neighboring States, S.C. Res. 955, U.N. SCOR,3453d Mtg. at 3., U.N. Doc. S/ RES/955, Annex (1994)

Statute of the International Criminal Tribunal for the Prosecution of Persons Responsible for Serious Violations of International Humanitarian Law Committed in the Territory of the Former Yugoslavia Since 1991, U.N. Doc. S/25704, Annex; Rome Statute of the International Criminal Court, United Nations, Treaty Series, vol. 2187, No. 38544

The unofficial translation of the message of H.E. President Recep Tayyip Erdogan, the then Prime Minister of the Republic of Turkey, on the events of 1915 (23 April 2014) http://www.mfa.gov.tr/turkish-prime-minister-mr_-recep-tayyip-erdo $\% \mathrm{C} 4 \% 9$ Fan-published-a-message-on-the-events-of-1915_-23-april-2014.en.mfa

UN Doc A/362, in GAOR, 2nd session 6th Committee, Summary Records, 16 September - 26 November 1947.

UN General Assembly, The Crime of Genocide, 11 December 1946, A/RES/96, elérhetö: https://www.refworld.org/docid/3b00f09753.html

US Congress H. Res. 296. (29 October 2019) https://www.congress.gov/116/bills/ hres296/BILLS-116hres296eh.pdf

\section{EGYÉB INTERNETES FORRÁSOK:}

https://asbarez.com/168067/european-court-finds-catholicosates-suit-inadmissible-and-could-not-be-appealed/

https://www.mfa.am/en/recognition/

http://www.mfa.gov.tr/the-armenian-allegation-of-genocide-the-issue-and-thefacts. n.mfa

http://www.mfa.gov.tr/controversy-between-turkey-and-armenia-about-theevents-of-1915.en.mfa https://www.whitehouse.gov/briefing-room/statements-releases/2021/04/24/ statement-by-president-joe-biden-on-armenian-remembrance-day/ 